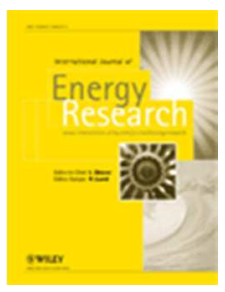

\title{
A Validation Study of Lithium-ion Cell Constant C-Rate Discharge Simulation with Battery Design Studio $®$
}

\begin{tabular}{|c|c|}
\hline Journal: & International Journal of Energy Research \\
\hline Manuscript ID: & ER-12-3000.R1 \\
\hline Wiley - Manuscript type: & Technical Note \\
\hline Date Submitted by the Author: & $\mathrm{n} / \mathrm{a}$ \\
\hline Complete List of Authors: & $\begin{array}{l}\text { Sakti, Apurba; Carnegie Mellon University, Engineering and Public Policy } \\
\text { Michalek, Jeremy J.; Carnegie Mellon University, Mechanical Engineering, } \\
\text { Engineering and Public Policy } \\
\text { Chun, Sang-Eun; Carnegie Mellon University, Materials Science and } \\
\text { Engineering } \\
\text { Whitacre, Jay F.; Carnegie Mellon University, Materials Science and } \\
\text { Engineering, Engineering and Public Policy }\end{array}$ \\
\hline Keywords: & $\begin{array}{l}\text { Battery Design Studio }{ }^{\circledR} \text {, Lithium-ion, Battery Performance Simulation, } \\
\text { Constant C-Rate Discharge, Validation }\end{array}$ \\
\hline
\end{tabular}

SCHOLARONE ${ }^{m}$

Manuscripts 
Sakti et al. 2012, Carnegie Mellon University

\section{List of Figures}

Figure 1: Flow diagram showing the methodology used in the validation study comparing three different data sources to verify Battery Design Studio ${ }^{\circledR}$

Figure 2: X-ray diffraction data collected form the cathode material has been shown in (i). X-ray diffraction data of $\mathrm{LiNi}_{0.33} \mathrm{Co}_{0.33} \mathrm{Mn}_{0.33} \mathrm{O}_{2}$ adapted from that reported by Yabuuchi and Obzuku [14] has been shown in (ii). The peaks match up indicating that the cathode active material is $\mathrm{LiNi}_{0.33} \mathrm{Co}_{0.33} \mathrm{Mn}_{0.33} \mathrm{O}_{2}$.

Figure 3: SEM micrographs of the cathode (left) and anode, used to estimate particle size.

Figure 4: Equilibrium potential curves used in Battery Design Studio ${ }^{\circledR}$ for the $\mathrm{LiNi}_{0.33} \mathrm{Co}_{0.33} \mathrm{Mn}_{0.33} \mathrm{O}_{2} / \mathrm{Li}_{\mathrm{x}} \mathrm{C}_{6}$ system.

Figure 5: (a-d) shows the comparison of the discharge curves at different C-rate discharges for Sanyo LiNiCoMn cells, while (e-h) show the same discharge curves plotted with respect to their state-of-charge (SoC). The $60 \%$ SoC window considered in the study has been shown with two vertical lines. The discharge Crates and the corresponding currents have been specified for each. The discharge rates were selected based on information in the manufacturer's data sheets to facilitate the comparison 

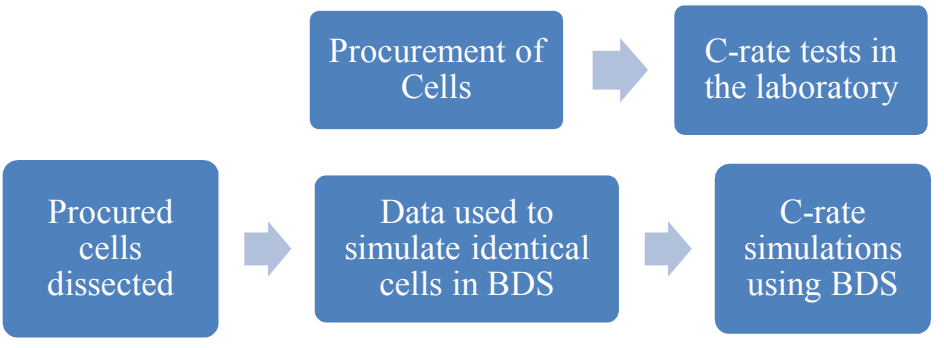

\section{Performance data from the cell manufacturer's specification sheet at different C-rates}

Figure 1: Flow diagram showing the methodology used in the validation

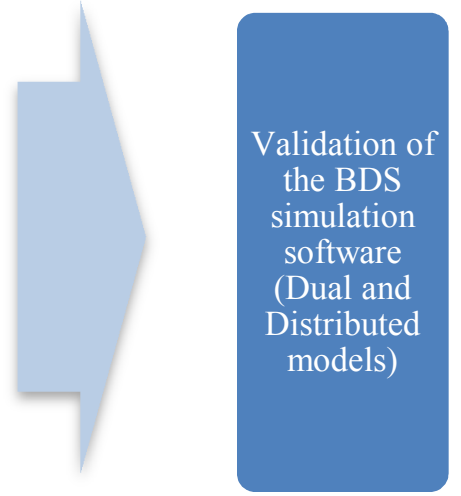
different data sources to verify Battery Design Studio ${ }^{\circledR}$. The Dual and Distributed IET (current, potential and temperature) models were used.

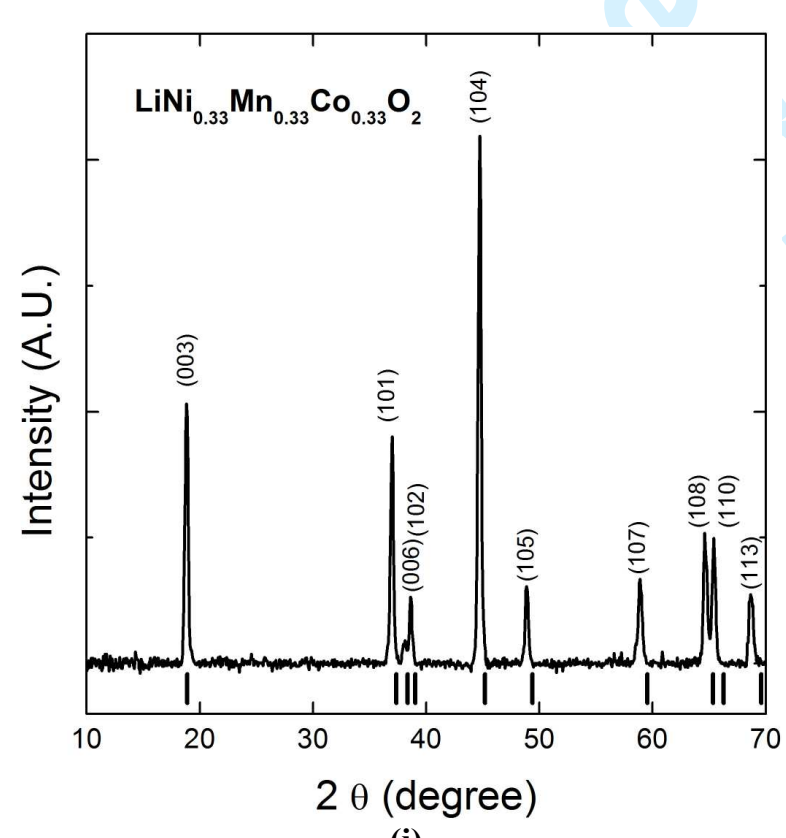

(i)

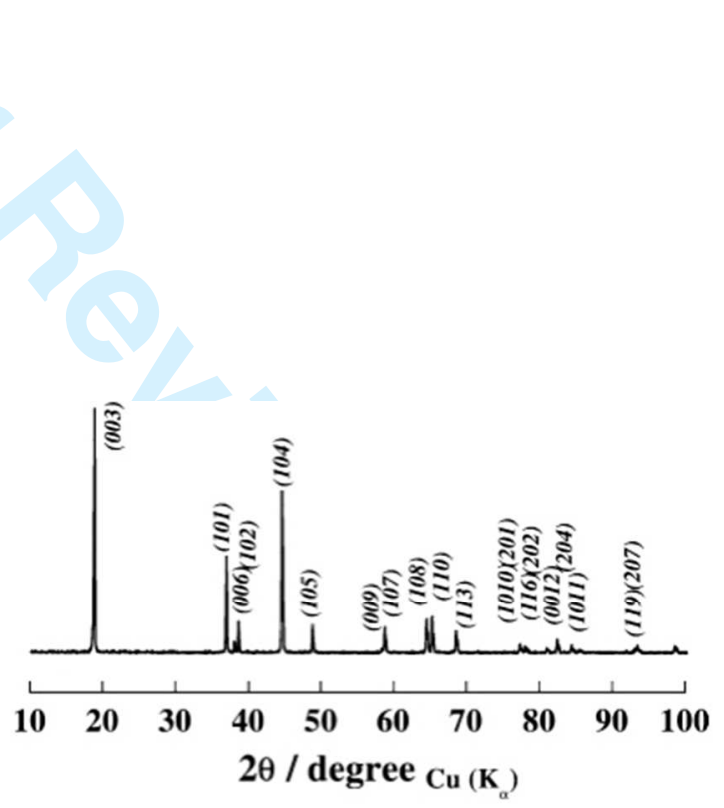

(ii)

Figure 2: X-ray diffraction data collected form the cathode material has been shown in (i). X-ray diffraction data of $\mathrm{LiNi}_{0.33} \mathrm{Co}_{0.33} \mathrm{Mn}_{0.33} \mathrm{O}_{2}$ adapted from that reported by Yabuuchi and Obzuku [14] has been shown in (ii). The peaks match up indicating that the cathode active material is $\mathrm{LiNi}_{0.33} \mathrm{Co}_{0.33} \mathrm{Mn}_{0.33} \mathrm{O}_{2}$. 

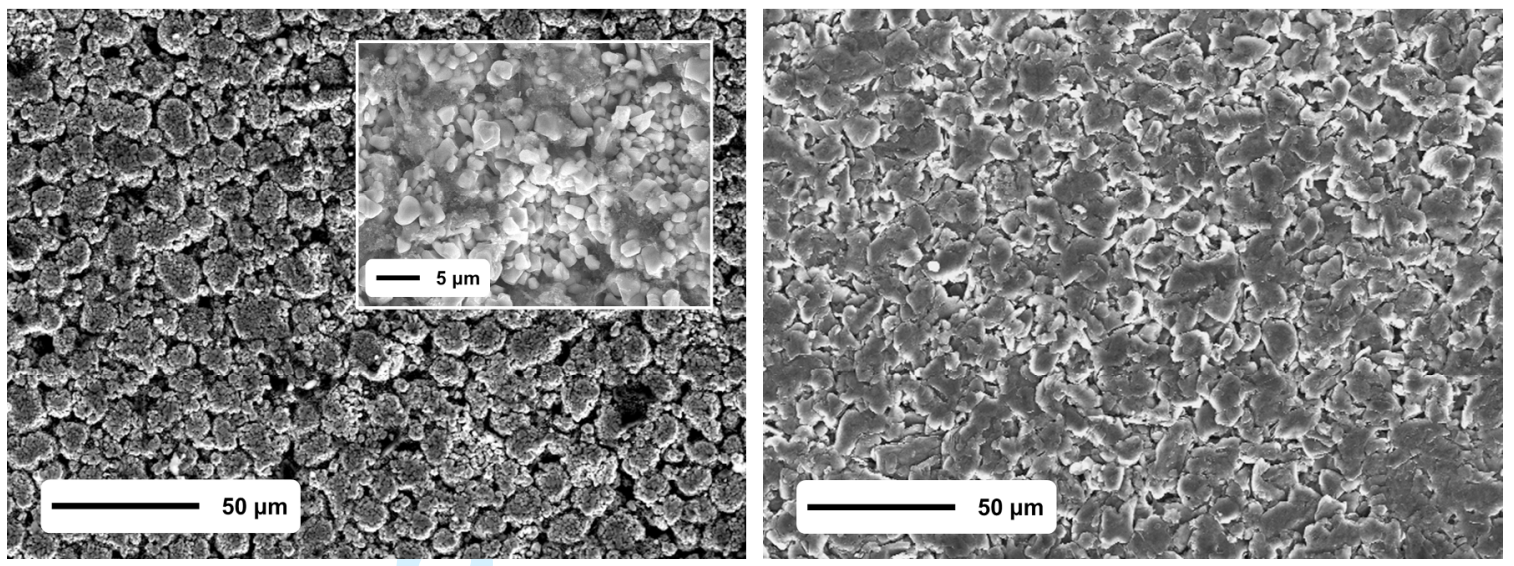

Figure 3: SEM micrographs of the cathode (left) and anode, used to estimate particle size.

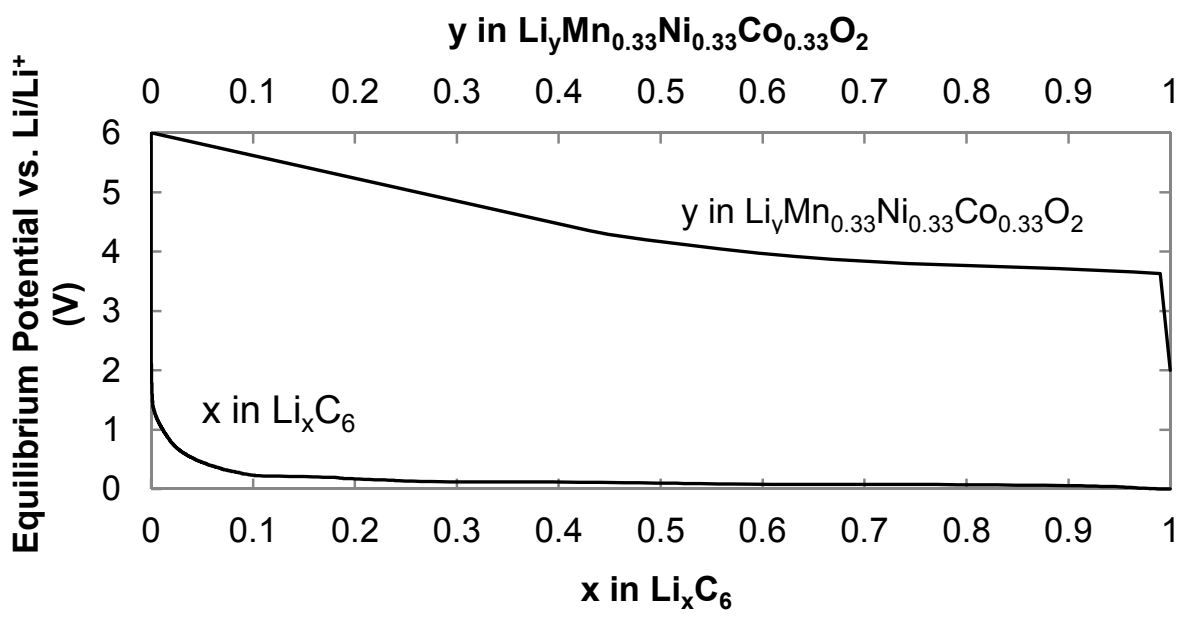

Figure 4: Equilibrium potential curves used in Battery Design Studio ${ }^{\circledR}$ for the $\mathrm{LiNi}_{0.33} \mathrm{Co}_{0.33} \mathrm{Mn}_{0.33} \mathrm{O}_{2} / \mathrm{Li}_{\mathrm{x}} \mathrm{C}_{6}$ system. 

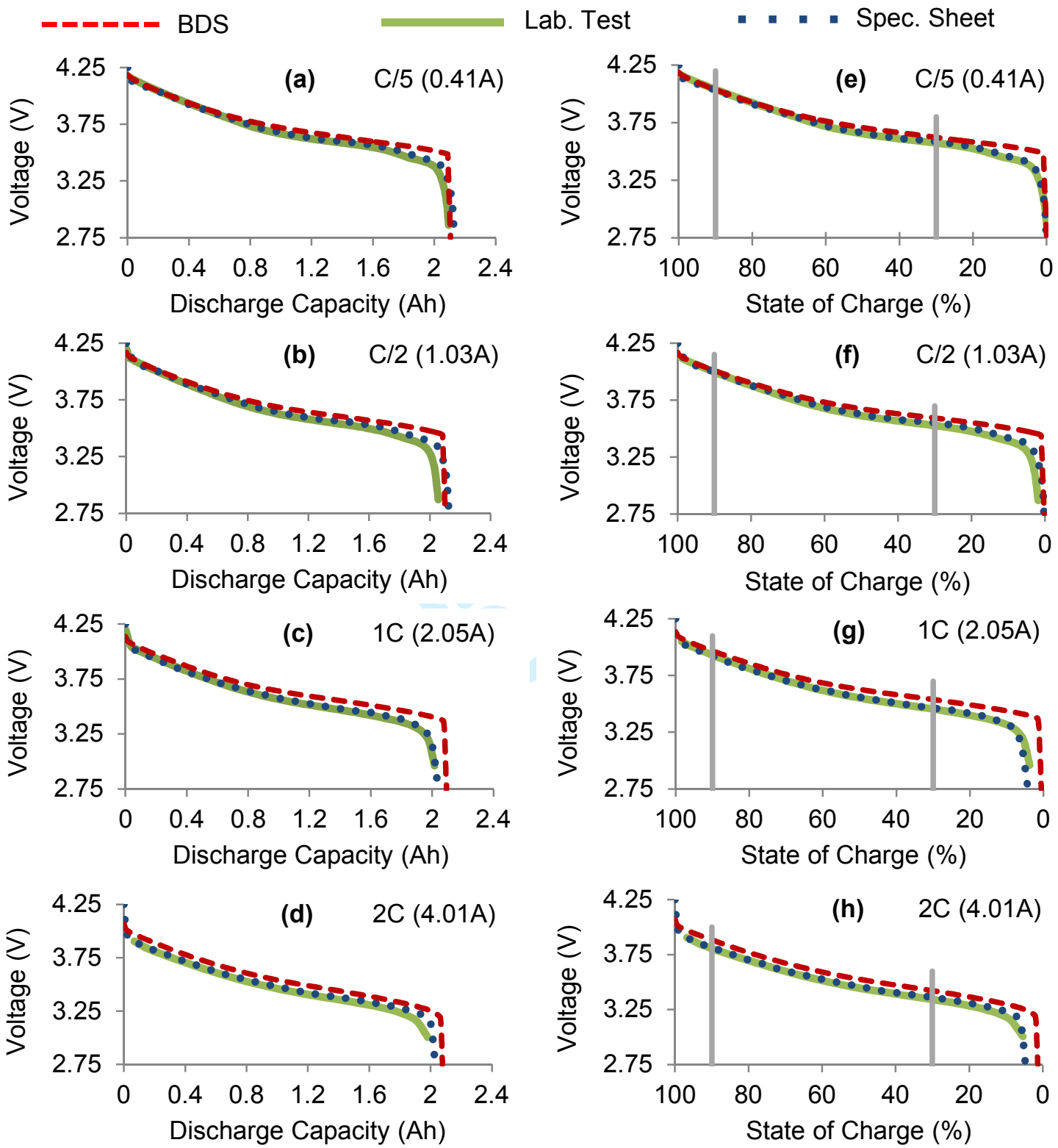

Figure 5: (a-d) shows the comparison of the discharge curves at different C-rate discharges for Sanyo LiNiCoMn cells, while (e-h) show the same discharge curves plotted with respect to their state-of-charge $(\mathrm{SoC})$. The $60 \% \mathrm{SoC}$ window considered in the study has been shown with two vertical lines. The discharge C-rates and the corresponding currents have been specified for each. The discharge rates were selected based on information in the manufacturer's data sheets to facilitate the comparison. 


\title{
A Validation Study of Lithium-ion Cell Constant C-Rate Discharge Simulation with Battery Design Studio ${ }^{\circledR}$ Apurba Sakti $^{\mathrm{a} 1}$, Jeremy J. Michalek ${ }^{\mathrm{a}, \mathrm{b}}$, Sang-Eun Chun ${ }^{\mathrm{c}}$, Jay F. Whitacre ${ }^{\mathrm{a}, \mathrm{c}}$ ${ }^{\mathrm{a}}$ Department of Engineering and Public Policy, ${ }^{\mathrm{b}}$ Department of Mechanical Engineering, ${ }^{c}$ Department of Materials Science and Engineering Carnegie Mellon University, Pittsburgh, PA 15213
}

\begin{abstract}
We compare battery performance simulations from a commercial lithium-ion battery modeling software package against manufacturer performance specifications and laboratory tests to assess model validity. A set of commercially manufactured spiral wound lithium-ion cells were electrochemically tested and then disassembled and physically characterized. The Battery Design Studio ${ }^{\circledR}$ (BDS) software was then used to create a mathematical model of each battery, and discharge simulations at constant Crates ranging from $\mathrm{C} / 5$ to $2 \mathrm{C}$ were compared against laboratory tests and manufacturer performance specifications. Results indicate that BDS predictions of total energy delivered under our constant C-rate battery discharge tests are within $6.5 \%$ of laboratory measurements for a full discharge and within $2.8 \%$ when a $60 \%$ state of charge window is considered. Average discrepancy is substantially lower. In all cases, the discrepancy in simulated vs. manufacturer specifications or laboratory results of energy and capacity delivered was comparable to the discrepancy between manufacturer specifications and laboratory results. Results suggest that BDS can provide sufficient accuracy in discharge performance simulations for many applications.
\end{abstract}

Keywords: Battery Design Studio ${ }^{\circledR}$; Lithium-ion; Battery Performance Simulation, Constant C-Rate Discharge; Validation

\footnotetext{
${ }^{1}$ Corresponding author. Tel: +1 412398 2088; fax: +1 412268 3757. E-mail address: asakti@cmu.edu
} 


\section{Introduction}

Existing battery modeling and simulation literature includes work on the general energy balance of a battery system [1], the heat generation rate using the energy balance model [2], electrochemical-thermal modeling and experimental validation [3], and the simulation and optimization of lithium-ion battery systems [4] amongst others that involve detailed calculations for the internal electrochemical processes using physicsbased models [5-9]. Models that avoid such detail and use approximations to represent a battery system with an equivalent circuit have also been developed and have been shown to match well with manufacturer's data [10]. However, in an equivalent circuit model, where common electrical components like resistors and capacitors are used to represent a battery system, the key elements of battery functionality that are related to ionic diffusion are very difficult to capture since modeling options there involve the use of multiple Warburg diffusion terms. The BDS battery simulation software provides versatility by allowing users to select from a set of battery system simulation models (which include both detailed physics based models as well as equivalent circuit ones) and run simulations through a graphical user interface. For this study, the model used is based on the same system of six coupled and non-linear discretized partial differential equations in the full system model described by Fuller et al. $[4]^{2}$, with time and space as the

\footnotetext{
2 The Distributed model was also used to simulate the cells at a later stage and the results were found to be the same.
} 
independent variables. Fuller et al. linearized and solved the equations using the BAND solver with the Crank-Nicholson implicit method to evaluate time derivatives [4]. The BAND solver, developed by Newman, uses tridiagonally banded matrices together with the Newton-Raphson method to solve finite difference representations of ordinary differential equations [11]. However, BDS uses a pentadiagonal BAND solver instead and implements more efficient data structures by saving only solid-phase concentrations at each time step. Cell temperature is determined from the overall energy balance calculations using the equations for insertion battery systems developed by Rao and Newman [2].

We aim to assess whether BDS is able to produce battery performance data that can be directly matched to Li-ion cells acquired on the open market. The main motivation behind this work is that a techno-economic optimization of lithium-ion battery packs for different electrified vehicles is currently in progress in which BDS is being used to predict the performance of the battery packs and this study was intended to ensure that the results from BDS are accurate enough to the extent of our economic modeling. To our knowledge, prior peer-reviewed validation work on BDS exists only for primary lithium ion coin cells in a study by Yeduvaka et al. [12]. Yeduvaka et al. discretized discharge curves obtained from manufacturer's data sheets (Sony, Panasonic, Gold Peak, Varta and Maxell) at different loads and temperatures and adjusted several cell parameters using 
BDS's built-in parameter estimation (optimization) feature to fit the discretized data. Yeduvaka et al. used Gering's AEM approach to estimate the electrolyte properties [13]. With the estimated parameters Yeduvaka et al. reported that the BDS model simulations match the discharge voltage behavior from the manufacturer's data sheet "fairly well" with greater discrepancies at higher positive electrode thicknesses $(3.457 \mathrm{~mm}$, Panasonic CR2354 and $1.8 \mathrm{~mm}$, Sony CR2032) and at temperatures less than $-10^{\circ} \mathrm{C}$. Yeduvaka et al. do not provide any metric to quantify the accuracy of their comparisons, but examining their data we find a discrepancy of around $10 \%$ between the BDS and the manufacturer's data sheet discharge curves at $23^{\circ} \mathrm{C}$ for the Sony CR2032 cell by integrating the area under the curves using the trapezoidal rule. Yeduvaka et al. suggested that this discrepancy between the actual and modeled data may be due to a difference in the assumed and actual electrolyte formulation. However, in their study, Yeduvaka et al. did not test the cells for their discharge performance in the laboratory. We expand on this prior work by testing vehicle-relevant secondary lithium ion cells of LiNiCoMn/graphite chemistry with cylindrical form factor in the laboratory and then comparing the results with the manufacturer's data sheet and the BDS simulations. We quantify the accuracy of the discharge curves, keeping in mind vehicle-relevant state-of-charge swings to determine the suitability of BDS for such modeling work. 


\section{Material and Methods}

To test the veracity of BDS, we compare battery discharge performance data (in the format of cell potential vs. discharged capacity at various current loadings) of a set of spirally wound 18650 cells with a $\mathrm{LiNi}_{0.33} \mathrm{Mn}_{0.33} \mathrm{Co}_{0.33} \mathrm{O}_{2}$ cathode active material chemistry and a minimum nominal capacity of 2.05Ah that were procured from Sanyo. The intended use of these cells, as listed by Sanyo, included electric vehicles [14] and could be implemented in the approach espoused by Tesla Motors Inc., where a large number of 18650 cells are connected in parallel and series to make a large format automotive pack. Data used to inform the comparisons were obtained from three sources:

i) lab tests performed on the cells, ii) the manufacturer's specification sheet, and iii) results from the BDS simulations. The co-ordinates of several points on the manufacturer's discharge curve specifications were read and used to approximate the manufacturer's discharge curve. The flow diagram shown in Figure 1 indicates the entire process.

\section{Figure 1}

The performance of the Sanyo LiNiCoMn cells was then tested in the laboratory under different C-rate discharges using an Arbin BT2000 test stand. For the sake of comparison, C-rates were chosen based on the discharge curves provided by the manufacturer in their specification sheet. Sample cells were then disassembled in the 
laboratory, and the following parameters were measured and used as BDS input:

electrode thickness and length, active material density, collector thickness, separator length and thickness, jellyroll weight, height and diameter, and cell weight. The exact chemistry of the cathode active material was determined using an X-ray diffractometer (X'Pert Pro MPD for powder samples) and the peaks correspond to those seen for $\mathrm{LiNi}_{0.33} \mathrm{Co}_{0.33} \mathrm{Mn}_{0.33} \mathrm{O}_{2}[15]$ as shown in Figure 2. Electrode structure and morphology in the electrode samples was estimated with the aid of scanning electron microscopy (SEM) (Philips, XL30). Plan-view SEM micrographs, shown in Figure 3, were obtained for the electrode samples and the average particle radius calculated. Table 1 summarizes the measured and calculated parameters for the cell. The density of $\mathrm{LiNi}_{0.33} \mathrm{Co}_{0.33} \mathrm{Mn}_{0.33} \mathrm{O}_{2}$ was calculated using the lattice dimensions reported by MacNeil et al. [16] and was found to be approximately $4.7 \mathrm{~g} / \mathrm{cm}^{3}$. The measured value of the coating density for the cathode, which included the binder and the conductivity aid, was found to be $3.0 \mathrm{~g} / \mathrm{cm}^{3}$. In the case of the anode, a coat density of $1.9 \mathrm{~g} / \mathrm{cm}^{3}$ was measured and the default graphite density of $2.25 \mathrm{~g} / \mathrm{cm}^{3}$ was assumed, which is similar to what has been reported elsewhere in the literature [17]. Other assumptions made while simulating the cells in BDS are shown in Table 2 and elaborated in the next section. The simulated cell was then subjected to the same C-rate discharge tests in BDS.

\section{Figure 2}

Figure 3

Table 1

Table 2 
Sakti et al. 2012, Carnegie Mellon University

\subsection{Assumptions}

Wherever possible, the parameters measured from the dissected cells were used as direct inputs in BDS. However, where data were not available reasonable assumptions were made. This is justifiable because many of the assumed values are common in the industry. For the density of the electrode active material, the mass fractions of the conductive additive and the binder along with the porosity fraction were varied in BDS within their usual ranges to identify plausible combinations that match the density values calculated from dissecting the physical cells in the laboratory. Both density and porosity estimates are consistent with simple analyses performed on the SEM data presented in Figure 3. The electrolyte was assumed to be $\mathrm{LiPF}_{6}$ dissolved in equal weight fractions of ethylene carbonate and ethyl methyl carbonate, a common blend used widely [18]. The separator was assumed to be polypropylene with a porosity of $40 \%$, an average value of porosity of separators available commercially [19]. The equilibrium cell potential curve along with all other parameters including the diffusion coefficient, resistivity, reaction rate constant, theoretical specific capacity, tortuosity, conductivity of the active materials (listed in Table 2) were values available in the BDS data base, which is updated frequently. The equilibrium cell potential curves have been shown in Figure 4 . The equilibrium cell potential curve of $\mathrm{LiNi}_{0.33} \mathrm{Co}_{0.33} \mathrm{Mn}_{0.33} \mathrm{O}_{2}$ was seen to be in general agreement with what has been reported in the literature for $\mathrm{Li}\left[\mathrm{Ni}_{\mathrm{x}} \mathrm{Co}_{1-2 \mathrm{x}} \mathrm{Mn}_{\mathrm{x}}\right] \mathrm{O}_{2}$ $(0 \leq \mathrm{x} \leq 1 / 2)[16]$. The theoretical capacity of $\mathrm{LiNi}_{0.33} \mathrm{Co}_{0.33} \mathrm{Mn}_{0.33} \mathrm{O}_{2}$ in the voltage range of $3-4.2 \mathrm{~V}$ was found to be around $120 \mathrm{mAh} / \mathrm{g}$ which is within the range of $110-130 \mathrm{mAh} / \mathrm{g}$ reported by MacNeil et al. for $\mathrm{Li}\left[\mathrm{Ni}_{\mathrm{x}} \mathrm{Co}_{1-2 \mathrm{x}} \mathrm{Mn}_{\mathrm{x}}\right] \mathrm{O}_{2}(0 \leq \mathrm{x} \leq 1 / 2)[16]$.

\section{Figure 4}


Sakti et al. 2012, Carnegie Mellon University

\section{Results and Discussion}

The comparison of the constant current discharge profiles for the cell is shown in Figure

5. The results from the laboratory match closely with the results from the manufacturer's specification sheet, and the results from the BDS simulations predict somewhat higher voltage over most of the range, particularly when mostly discharged. Table 4 summarizes the difference between delivered energy and delivered capacity measured using BDS, laboratory tests, and the manufacturer specification sheet. Delivered energy in the case of the manufacturer's specification sheet was computed by calculating the area under each of the curves using the trapezoidal rule by selecting points at most $0.1 \mathrm{Ah}$ apart. In the case of the BDS simulations, reporting parameters of $10 \mathrm{~s}$ and $0.1 \mathrm{~V}$ were selected, leading to results with a resolution within $0.01 \mathrm{Ah}^{\ddagger}$. Laboratory results using the Arbin BT2000 test stand reported values using a much higher resolution. The cell simulations predicted capacity and energy within $4.3 \%$ of manufacturer specification and within $6.5 \%$ of lab tests. Average discrepancies for the cell simulations are substantially lower.

The discharge profiles were also compared under a reduced $60 \%$ state of charge (SoC) window. This was done to simulate similar conditions encountered in some battery applications, such as vehicle applications (e.g.: the Chevy Volt battery pack operates within a $65 \%$ SoC window [20]). In this case, the magnitude of this state of charge swing (in Ah) was calculated based on the measured or modeled total capacity value for each case (Figure 3). The curves were then compared between the 30\%-90\% SoC window for the energy and capacity delivered. BDS results match more closely within the $60 \%$ SoC. The cell simulations predicted energy and capacity values within $1.6 \%$ of manufacturer

\footnotetext{
$\$$ Simulations with a tighter resolution of $0.5 \mathrm{~s}$ produced similar energy and capacity results within $0.2 \%$, and tests with a more coarse resolution of 1 min produced results within $0.1 \%$.
} 
specification and within $2.8 \%$ of lab tests. Again, average discrepancies for the cell simulations are substantially lower. The average and maximum difference in the voltage between the discharge curves from the manufacturer's specification sheet and the laboratory results vs. the BDS simulation results within this SoC window were also calculated (Table 4). The maximum difference is within $0.08 \mathrm{~V}$ of manufacturer specification and $0.09 \mathrm{~V}$ of lab results. Average voltage discrepancies are lower.

\section{Figure 5}

Table 3

\section{Table 4}

\section{Conclusion}

The energy and capacity calculated from constant C-rate discharge curves simulated using Battery Design Studio® for the Sanyo LiNiCoMn cells were found to be within $6.5 \%$ and $4.8 \%$ of laboratory data for a full discharge, respectively, and within $2.8 \%$ and an exact match of laboratory data for a $60 \%$ state of charge window, respectively. Average discrepancies are substantially lower and are comparable to discrepancies between laboratory tests and manufacturer specifications. Results indicate that relatively accurate performance predictions are possible using BDS if appropriate parameters are used. Furthermore, by showing agreement between actual data and modeled performance through a range of discharge currents, we provide evidence that this model is able to accurately represent key elements of battery functionality that are related to ionic diffusion through the system. 
Sakti et al. 2012, Carnegie Mellon University

\section{Limitations}

We examine only constant C-rate discharge at room temperature and do not explicitly test charging, variable rate discharge, or elevated temperature. Due to the unavailability of higher C-rate discharge performance from the manufacturer, the C-rates chosen for the discharges were also lower than what is likely to be encountered in electrified vehicle applications. We also use assumed default values for several unknown cell parameters, such as the diffusion coefficient, resistivity, reaction rate constant, tortuosity, and conductivity of the active materials. Model fit might be expected to improve if precise measurements of these parameters were used.

\section{Acknowledgements}

The authors wish to thank Robert Spotnitz and Gowri Yeduvaka of Battery Design LLC for their valuable guidance during the course of this study. The authors would also like to thank Aquion Energy for use of laboratory facilities. This research was supported in part by support from Gordon and Betty Moore Foundation, a grant from the National Science Foundation, CAREER grant \# 0747911, and a grant from Toyota Motor Corporation. The findings and views expressed are those of the authors and not necessarily those of the sponsors. 


\section{References}

1. Bernardi D, Pawlikowski E, Newman J. A general energy balance for battery systems. Journal of Electrochemical Society 1985; 132: 5-12.

2. Rao L, Newman J. Heat-generation rate and general energy balance for insertion battery systems. Journal of Electrochemical Society 1997; 144: 2697-04.

3.Fang W, Kwon OJ, Wang C-Y. Electrochemical-thermal modeling of automotive Li-ion batteries and experimental validation using a three-electrode cell. International Journal of Energy Research 2010; 34: $107-12$

4. Fuller TF, Doyle M, Newman J. Simulation and optimization of the dual lithium ion insertion cell. Journal of Electrochemical Society 1994; 141: 1-10.

5. Doyle M, Fuller TF, Newman J. Modeling of galvanostatic charge and discharge of the lithium/polymer/insertion cell. Journal of Electrochemical Society 1993; 140: 1526-33.

6. Doyle M, Newman J, Gozdz AS, Schmutz CN, Tarascon J. Comparison of modeling predictions with experimental data from plastic lithium ion cells. Journal of Electrochemical Society 1996; 143: 189003.

7. Arora P, Doyle M, White RE. Mathematical modeling of the lithium deposition overcharge reaction in lithium-ion batteries using carbon-based negative electrodes. Journal of Electrochemical Society 1999; 146: $3543-53$.

8. Song L, Evans JW. Electrochemical-thermal model of lithium polymer batteries. Journal of Electrochemical Society 2000; 147: 2086-95.

9. Gu WB, Wang CY. Thermal-electrochemical modeling of battery systems. Journal of Electrochemical Society 2000; 147: 2910-22.

10. Gao L, Shengyi L, Dougal RA. Dynamic lithium-ion battery model for system simulation. IEEE Transactions on Components and Packaging Technology 2002; 25: 495-05.

11. Spotnitz RM. NL3BO, A framework for electrochemical systems. Electrochemical Society Proceedings 1999; 99(14): 242- 9 .

12. Yeduvaka GS, Spotnitz RM, Gering KL. Macro-homogenous modeling of commercial. Primary Li/ $\mathrm{MnO}_{2}$ coin cells. Electrochemical Society Transactions 2009; 19(16): 1-10. 
Sakti et al. 2012, Carnegie Mellon University

13. Gering KL. Prediction of electrolyte viscosity for aqueous and non-aqueous systems: Results from a molecular model based on ion solvation and a chemical physics framework. Electrochemica Acta 2006; 51: 3125-38.

14. Standard Electric Company [Internet]. Japan. Sanyo lithium ion rechargeable batteries; [updated 2009, cited 2012 Jul 18] Available from: http://www.stnd.co.jp/aspx/Class/Class2_2ELithiumIon.2009_E.PDF

15. Yabuuchi N, Ohzuku T. Novel lithium insertion material of $\mathrm{LiCo}_{1 / 3} \mathrm{Ni}_{1 / 3} \mathrm{Mn}_{1 / 3} \mathrm{O}_{2}$ for advanced lithiumion batteries. Journal of Power Sources 2003; 119-121: 171-74.

16. Macneil DD, Lu Z, Dahn JR. Structure and Electrochemistry of $\mathrm{Li}\left[\mathrm{Ni}_{\mathrm{x}} \mathrm{Co}_{1-2 \mathrm{x}} \mathrm{Mn}_{\mathrm{x}}\right] \mathrm{O}_{2}(0 \leq \mathrm{x} \leq 1 / 2)$. Journal of Electrochemical Society 2002; 149: A1332-36.

17. Robertson J. Properties of diamond-like carbon. Surface and Coatings Technology 1992; 50(3): 185-03.

18. Ehlrich GM. Lithium-ion batteries. In: Linden D, Reddy TB, editors. Handbook of Batteries. New York: McGraw-Hill, 2002, p 35.22.

19. Ehlrich GM. Lithium-ion batteries. In: Linden D, Reddy TB, editors. Handbook of Batteries. New York: McGraw-Hill, 2002, p 35.29.

20. General Motors [Internet]. USA. Volt introduces revolutionary Voltec system; [updated 2011 Sept 12; cited 2012 Jul 18]. Available from: http://media.gm.com/content/media/us/en/gm/news.detail.html/content/Pages/news/au/en/2011/Dec/1209_ VoltIntroducesRevolutionaryVoltecSystem.html 
Sakti et al. 2012, Carnegie Mellon University

\section{List of Tables}

Table 1: Measured and calculated parameters from the Sanyo LiNiCoMn cell after dissecting them in the laboratory

Table 2: Assumptions made for different parameters while simulating the cells using BDS

Table 3: The total delivered energy (Wh), calculated by integrating the discharge curve, along with the capacity (Ah) values as shown in Figure 2. The percent difference of the values with respect to the BDS simulation results has been indicated in parenthesis.

Table 4: The total delivered energy (Wh), calculated by integrating the discharge curve, along with the capacity (Ah) values for a $60 \%$ state of charge window as shown in Figure 3 . The percent difference of the values with respect to the BDS simulation results is indicated in parenthesis. The average difference in voltage within the $\mathrm{SoC}$ window has also been listed along with the maximum voltage difference in parenthesis. 
Sakti et al. 2012, Carnegie Mellon University

Table 1: Measured and calculated parameters from the Sanyo LiNiCoMn cell after dissecting them in the laboratory

\begin{tabular}{|c|c|c|}
\hline $\begin{array}{l}\text { Cell } \\
\quad \text { Weight (g) }\end{array}$ & \multicolumn{2}{|c|}{$42(+/-1)$} \\
\hline \multicolumn{3}{|l|}{ Jellyroll } \\
\hline Height $(\mathrm{cm})$ & \multicolumn{2}{|c|}{$5.6(+/-0.1)$} \\
\hline Length $(\mathrm{cm})$ & \multicolumn{2}{|c|}{$78.7(+/-0.1)$} \\
\hline \multicolumn{3}{|l|}{ Separator } \\
\hline Length $(\mathrm{cm})$ & \multirow{2}{*}{\multicolumn{2}{|c|}{$\begin{array}{c}162(+/-1) \\
0.015((+/-0.001)\end{array}$}} \\
\hline Thickness (mm) & & \\
\hline Electrodes & Cathode & Anode \\
\hline Chemistry (cathode from XRD) & $\mathrm{LiNi}_{0.33} \mathrm{Co}_{0.33} \mathrm{Mn}_{0.33} \mathrm{O}_{2}$ & graphite \\
\hline Active material density $\left(\mathrm{g} / \mathrm{cm}^{3}\right)$ & 4.7 & $-*$ \\
\hline Single side coat thickness (mm) & $0.15(+/-0.01)$ & $0.14(+/-0.01)$ \\
\hline Collector thickness $(\mathrm{Al})(\mathrm{mm})$ & $0.014(+/-0.001)$ & $0.016(+/-0.001)$ \\
\hline Coat density $\left(\mathrm{g} / \mathrm{cm}^{3}\right)$ & $3.0(+/-0.1)$ & $1.9(+/-0.1)$ \\
\hline Particle radius from SEM $(\mu \mathrm{m})$ & $0.98(+/-0.05)$ & $7.78(+/-0.05)$ \\
\hline
\end{tabular}

*The default density value of $2.25 \mathrm{~g} / \mathrm{cm}^{3}$ was assumed, which was found to be similar to what has been reported elsewhere in the literature [16]

Table 2: Assumptions made for different parameters while simulating the cells using BDS

\begin{tabular}{|c|c|c|}
\hline Electrode Parameters & Cathode & Anode \\
\hline Mass fraction active material & 0.84 & 0.96 \\
\hline Mass fraction binder (ethylene-propylene copolymer) & 0.03 & 0.015 \\
\hline Mass fraction of conductive aid (graphite) & 0.13 & 0.025 \\
\hline Porosity fraction & 0.195 & 0.17 \\
\hline Active material diffusion coefficient (solid) $\left(\mathrm{cm}^{2} / \mathrm{s}\right.$ at $\left.25^{\circ} \mathrm{C}\right)$ & $3 \mathrm{E}-11$ & $6.74 \mathrm{E}-11$ \\
\hline $\begin{array}{l}\text { Active material lithium site concentration before formation } \\
\text { (used to calculate the stoichiometry) (mAh/g) }\end{array}$ & 275 & 370 \\
\hline Resistivity $\left(\Omega \mathrm{m}^{2}\right.$ at $\left.25^{\circ} \mathrm{C}\right)$ & $6 \mathrm{E}-3$ & 0.5 \\
\hline Reaction rate constant $\left(\mathrm{mA} / \mathrm{cm}^{2}\right)$ & $1.08 \mathrm{E} 2$ & $2.02 \mathrm{E}-01$ \\
\hline Electrode conductivity $(\mathrm{S} / \mathrm{cm})$ & 100 & 100 \\
\hline Tortuosity (Bruggemann Exp) & 1.25 & 1.9 \\
\hline Other Parameters & & \\
\hline Initial salt concentration, $\mathrm{LiPF}_{6}$ in $\mathrm{EC}: \mathrm{EMC}(\mathrm{M})$ & \multicolumn{2}{|c|}{1.0} \\
\hline Electrolyte density $\left(\mathrm{g} / \mathrm{cm}^{3}\right)$ & \multicolumn{2}{|c|}{1.25} \\
\hline Separator material (polypropylene) density $\left(\mathrm{g} / \mathrm{cm}^{3}\right)$ & \multicolumn{2}{|c|}{0.65} \\
\hline Aluminum density $\left(\mathrm{g} / \mathrm{cm}^{3}\right)$ & \multicolumn{2}{|c|}{2.7} \\
\hline Copper density $\left(\mathrm{g} / \mathrm{cm}^{3}\right)$ & \multicolumn{2}{|c|}{8.9} \\
\hline
\end{tabular}


Table 3: The total delivered energy (Wh), calculated by integrating the discharge curve, along with the capacity (Ah) values as shown in Figure 2. The percent difference of the values with respect to the BDS simulation results has been indicated in parenthesis.

\begin{tabular}{ccc|cc|cc}
\hline & \multicolumn{2}{c}{$\begin{array}{c}\text { BDS Simulation } \\
\text { Results }\end{array}$} & \multicolumn{2}{c}{$\begin{array}{c}\text { Manufacturer's } \\
\text { Specification Sheet }\end{array}$} & \multicolumn{2}{c}{ Laboratory Results } \\
\hline $\begin{array}{c}\text { Discharge Rate } \\
(\text { Current) }\end{array}$ & $\begin{array}{c}\text { Capacity } \\
\text { (Ah) }\end{array}$ & $\begin{array}{c}\text { Energy } \\
(\text { Wh })\end{array}$ & $\begin{array}{c}\text { Capacity } \\
\text { (Ah) }\end{array}$ & $\begin{array}{c}\text { Energy } \\
\text { (Wh) }\end{array}$ & $\begin{array}{c}\text { Capacity } \\
\text { (Ah) }\end{array}$ & $\begin{array}{c}\text { Energy } \\
(\text { Wh) }\end{array}$ \\
\hline C/5 (0.41A) & 2.11 & 7.89 & $2.13(0.9)$ & $7.89(0.0)$ & $2.09(-0.9)$ & $7.75(-1.8)$ \\
C/2 (1.03A) & 2.10 & 7.81 & $2.13(1.4)$ & $7.80(-0.1)$ & $2.05(-2.4)$ & $7.53(-3.6)$ \\
$1 \mathrm{C}(2.05 \mathrm{~A})$ & 2.09 & 7.68 & $2.04(-2.4)$ & $7.35(-4.3)$ & $2.02(-3.3)$ & $7.26(-5.5)$ \\
2C $(4.1 \mathrm{~A})$ & 2.08 & 7.41 & $2.03(-2.4)$ & $7.13(-3.8)$ & $1.98(-4.8)$ & $6.93(-6.5)$ \\
\hline
\end{tabular}

Table 4: The total delivered energy (Wh), calculated by integrating the discharge curve, along with the capacity (Ah) values for a $60 \%$ state of charge window as shown in Figure 3 . The percent difference of the values with respect to the BDS simulation results is indicated in parenthesis. The average difference in voltage within the state-of-charge $(\mathrm{SoC})$ window has also been listed along with the maximum voltage difference in parenthesis.

\begin{tabular}{|c|c|c|c|c|c|c|c|c|}
\hline \multirow[b]{2}{*}{$\begin{array}{c}\text { Discharge } \\
\text { Rate (Current) }\end{array}$} & \multicolumn{2}{|c|}{$\begin{array}{l}\text { BDS Simulation } \\
\text { Results }\end{array}$} & \multicolumn{3}{|c|}{$\begin{array}{c}\text { Manufacturer's Specification } \\
\text { Sheet }\end{array}$} & \multicolumn{3}{|c|}{ Laboratory Results } \\
\hline & $\begin{array}{l}\text { Capacity } \\
\text { (Ah) }\end{array}$ & $\begin{array}{l}\text { Energy } \\
(\mathrm{Wh})\end{array}$ & $\begin{array}{l}\text { Capacity } \\
\text { (Ah) }\end{array}$ & $\begin{array}{l}\text { Energy } \\
\text { (Wh) }\end{array}$ & $\begin{array}{c}\text { Avg. } \\
\text { (Max) } \\
\text { V diff. } \\
\text { (V) }\end{array}$ & $\begin{array}{l}\text { Capacity } \\
\text { (Ah) }\end{array}$ & $\begin{array}{c}\text { Energy } \\
\text { (Wh) }\end{array}$ & $\begin{array}{c}\text { Avg. } \\
\text { (Max) } \\
\text { V diff. } \\
\text { (V) }\end{array}$ \\
\hline $\mathrm{C} / 5(0.41 \mathrm{~A})$ & 1.26 & 4.79 & $\begin{array}{l}1.28 \\
(1.6)\end{array}$ & $\begin{array}{l}4.80 \\
(0.2)\end{array}$ & $\begin{array}{l}-0.03 \\
(-0.05)\end{array}$ & $\begin{array}{l}1.26 \\
(0.0)\end{array}$ & $\begin{array}{l}4.72 \\
(-1.5)\end{array}$ & $\begin{array}{c}-0.04 \\
(-0.05)\end{array}$ \\
\hline $\mathrm{C} / 2(1.03 \mathrm{~A})$ & 1.26 & 4.75 & $\begin{array}{l}1.28 \\
(1.6)\end{array}$ & $\begin{array}{l}4.76 \\
(0.2)\end{array}$ & $\begin{array}{l}-0.03 \\
(-0.05)\end{array}$ & $\begin{array}{l}1.26 \\
(0.0)\end{array}$ & $\begin{array}{l}4.66 \\
(-1.9)\end{array}$ & $\begin{array}{l}-0.05 \\
(-0.07)\end{array}$ \\
\hline $1 \mathrm{C}(2.05 \mathrm{~A})$ & 1.26 & 4.69 & $\begin{array}{l}1.28 \\
(1.6)\end{array}$ & $\begin{array}{l}4.66 \\
(-0.6)\end{array}$ & $\begin{array}{l}-0.06 \\
(-0.08)\end{array}$ & $\begin{array}{l}1.26 \\
(0.0)\end{array}$ & $\begin{array}{l}4.58 \\
(-2.3)\end{array}$ & $\begin{array}{l}-0.06 \\
(-0.09)\end{array}$ \\
\hline $2 \mathrm{C}(4.1 \mathrm{~A})$ & 1.26 & 4.57 & $\begin{array}{l}1.28 \\
(1.6)\end{array}$ & $\begin{array}{c}4.54 \\
(-0.7)\end{array}$ & $\begin{array}{l}-0.07 \\
(-0.07)\end{array}$ & $\begin{array}{l}1.26 \\
(0.0)\end{array}$ & $\begin{array}{c}4.44 \\
(-2.8)\end{array}$ & $\begin{array}{c}-0.09 \\
(-0.08)\end{array}$ \\
\hline
\end{tabular}

